\title{
Peripheral Tissue Mechanism for Maintenance of Serum Triiodothyronine Values in a Thyroxine-deficient State in Man
}

Steven M. C. Lum, John T. Nicoloff, Carole A. Spencer, and Elaine M. Kaptein

University of Southern California School of Medicine, Los Angeles, California 90033

bstract. The present study was undertaken to define the source of endogenous triiodothyronine (T3) production responsible for maintaining serum T3 levels in euthyroid subjects with depressed serum thyroxine (T4) values. After withdrawal from 4 wk of exogenous T3 administration, a $22 \%$ decline in serum T3 values (from $129 \pm 6$ to $99 \pm 4 \mathrm{ng} / \mathrm{dl}$ ) was observed in six euthyroid subjects, despite a twofold reduction in serum $\mathrm{T} 4$ concentrations (from $7.5 \pm 0.5$ to $3.2 \pm 0.5 \mu \mathrm{g} / \mathrm{dl}$ ). This was accompanied by a nearly twofold increase in serum T3/T4 ratio values ( $17 \pm 1$ to $29 \pm 6$ ) but no significant alteration in reverse T3/T4 ratio values. This phenomenon did not appear to be thyroid stimulating hormone (TSH) dependent, since base-line serum TSH values were subnormal. Nor was it dependent on changes in thyroid gland function, since a blunted $\mathrm{T} 3$ response to exogenous bovine TSH occurred and pharmacologic doses of iodide did not influence the phenomenon. The finding in three athyreotic subjects that serum T3/T4 ratio values increased from $14 \pm 1$ on $\mathrm{T} 4$ therapy (mean serum $\mathrm{T} 4,9.6 \pm 0.8 \mu \mathrm{g} / \mathrm{dl}$ and T3, $132 \pm 8 \mathrm{ng} / \mathrm{dl}$ ) to $40 \pm 2$ after withdrawal from 2 wk of T3 administration (serum T4 1.2 $\pm 0.1 \mu \mathrm{g} / \mathrm{dl}$ and T3 $46 \pm 3 \mathrm{ng} / \mathrm{dl}$ ) provided direct evidence that an alteration in peripheral thyroid hormone metabolism was probably responsible for these findings previously observed in euthyroid subjects. The results of this study support the possible existence in euthyroid man of a peripheral tissue autoregulatory mechanism for maintaining serum T3 values in states of T4 deficiency. Whether this process

\footnotetext{
Address all correspondence to Dr. Nicoloff. 1983.

Received for publication 26 August 1982 and in revised form 9 August
}

J. Clin. Invest.

(C) The American Society for Clinical Investigation, Inc. 0021-9738/84/02/0570/06

Volume 73, February 1984, 570-575 involves an alteration in the efficiency of T4 to T3 conversion or the rate of T3 clearance is presently unknown.

\section{Introduction}

It is axiomatic that thyroid stimulating hormone (TSH)' secretion plays a critical role in regulating thyroid gland function and, in turn, circulating thyroid hormone levels (1-5). For example, elevations in serum TSH induced preferential thyroidal triiodothyronine (T3) formation and secretion tend to maintain serum $\mathrm{T} 3$ values as circulating thyroxine (T4) levels fall as a result of either thyroid disease or iodine deficiency (2). This centrally controlled "autoregulation" appears to be dependent upon intrapituitary conversion of T4 to T3, which serves to amplify the TSH response to even minimal decreases in circulating levels of $\mathrm{T} 4(2,6,7)$. The recent demonstration of a TSH inducible thyroidal 5'-deiodinase system acting to increase T3 secretion may be an additional mechanism for maintaining circulating T3 levels $(8,9)$.

Despite the demonstrated alterations in thyroid glandular secretion in states of T4 deficiency, most of the circulating T3 present in euthyroid man is normally derived from T4 to T3 conversion by peripheral tissue rather than by direct thyroidal secretion $(10,11)$. Although this peripheral conversion process may be affected by such altered metabolic states as fasting, overfeeding, and various system illnesses (10-16), there is little evidence that this peripheral tissue mechanism is important in maintaining circulating $\mathrm{T} 3$ levels when serum $\mathrm{T} 4$ concentrations are depressed. This study purports to find evidence that a nonthyroidal, non-TSH-mediated system exists for maintaining circulating $\mathrm{T} 3$ levels in a state of T4 deficiency.

\section{Methods}

Studies were performed in 13 normal (10 males, 3 females) and 11 euthyroid athyreotic (females) subjects, ranging in age from 20 to 50 yr. Normal subjects were screened for thyroid disease by history, physical examination, and serum thyroid hormone indices. Those comprising

1. Abbreviations used in this paper: rT3, reverse T3; SSKI, supersaturated solution of potassium iodide; T3, triiodothyronine; T4, thyroxine; TSH, thyroid stimulating hormone. 
the athyreotic group had been shown to have primary hypothyroidism based on serum T4 concentrations of $<1.0 \mu \mathrm{g} / \mathrm{dl}$ and serum TSH values of $>40 \mu \mathrm{U} / \mathrm{ml}$. The athyreotic subjects had been maintained on exogenous thyroxine replacement therapy for longer than one year, and all were clinically and biochemically euthyroid at the time of study. Written informed consents were obtained from all study subjects before the initiation of the protocol.

The normal subjects were placed on T3 doses of $50 \mu \mathrm{g}$ daily the 1st wk, $75 \mu \mathrm{g}$ daily the $2 \mathrm{nd}$ wk; and $100 \mu \mathrm{g}$ daily for the last $10 \mathrm{~d}$. Six of these subjects were on T3 therapy alone and then withdrawn (control group), while seven subjects were given T3 therapy $500 \mathrm{mg}$ of iodide daily supersaturated solution of potassium iodide (SSKI). Blood samples were drawn daily at $0800-1200 \mathrm{~h}$ or $2-4 \mathrm{~h}$ after the daily T3 dose.

Three subjects from the control group had a TSH stimulation test performed before and on the 3rd d after T3 withdrawal. Serum T3 and T4 measurements were performed at 2-h intervals for $8 \mathrm{~h}$ after the intramuscular administration of $2 \mathrm{U}$ of bovine TSH (Armour Pharmaceutical Co., Tarrytown, NY).

The athyreotic patients were switched from oral thyroxine replacement to oral T3 (Cytomel; Smith Kline Corp., Philadelphia, PA), 75 $\mu \mathrm{g}$ daily. In three patients, T3 therapy was discontinued after $2 \mathrm{wk}$, while in 8 patients, the T3 therapy was continued for 6 wk and one subject for $12 \mathrm{wk}$. After the cessation of $\mathrm{T} 3$ all subjects remained off thyroid medication for $8 \mathrm{~d}$.

Total serum T4, T3, and reverse T3 (rT3) measurements were performed in duplicate by a double antibody radioimmunoassay technique (17). The serum T4 assay sensitivity was $0.25 \mu \mathrm{g} / \mathrm{dl}$ with intraassay variabilities $5.1 \%$ at $1.7 \mu \mathrm{g} / \mathrm{dl}$ and $1.6 \%$ at both 5.0 and $10.4 \mu \mathrm{g} / \mathrm{dl}$, respectively. The serum $\mathrm{T} 3$ assay sensitivity was $10 \mathrm{ng} / \mathrm{dl}$, with an intraassay variability of $2.9 \%$ at $97 \mathrm{ng} / \mathrm{dl}$ and $1.5 \%$ at $203 \mathrm{ng} / \mathrm{dl}$. The serum rT3 assay sensitivity limit was $10 \mathrm{ng} / \mathrm{dl}$, with an intraassay variability of $3.8 \%$ at $70 \mathrm{ng} / \mathrm{dl}$ and $3.3 \%$ at $195 \mathrm{ng} / \mathrm{dl}$. The mean normal total serum rT3 was $34 \pm 1.5 \mathrm{ng} / \mathrm{dl}(n=62)$. The cross reactivity of the rT3 antibody with T4 was $0.019 \%$. Serum TSH measurements were performed by a previously reported modification of a double antibody technique designed to assess low serum TSH concentrations (18). Nominal assay sensitivity was $0.1 \mu \mathrm{U} / \mathrm{ml}$ with an intraassay variability value of $12.9 \%$ at $0.58 \mu \mathrm{U} / \mathrm{ml}, 8.4 \%$ at $1.5 \mu \mathrm{U} / \mathrm{ml}$, and $5.8 \%$ at $2.83 \mu \mathrm{U} / \mathrm{ml}$. Serum T3/T4 ratios were expressed by dividing the serum $T 3$ value in nanograms per deciliter by the T4 value in micrograms per deciliter. The molar ratio concentrations of T3 and T4 in the serum can be obtained by multiplying reported values by $1.194 \times 10^{-3}$.

\section{Results}

Findings in the euthyroid control group during and after T3 administration are shown in Fig. 1. Mean base-line values of total serum T4 of $7.5 \pm 0.5 \mu \mathrm{g} / \mathrm{dl}( \pm \mathrm{SEM})$, serum T3 of $129 \pm 6$ $\mathrm{ng} / \mathrm{dl}$, and TSH of $2.0 \pm 0.5 \mu \mathrm{U} / \mathrm{dl}$ were all within the normal range. After oral T3, mean TSH values promptly declined to subnormal levels of $0.4 \pm 0.1 \mu \mathrm{U} / \mathrm{ml}$. Serum T4 concentrations fell gradually, reaching a nadir value of $3.1 \pm 0.3 \mu \mathrm{g} / \mathrm{dl}$ on day 28. Mean serum $T 3$ values progressively rose with increasing $\mathrm{T} 3$, reaching peak values of $498 \pm 51 \mathrm{ng} / \mathrm{dl}$ on day 28 . Elevations in serum $\mathrm{T} 3$ were a reflection of the ingestion of the daily morning oral T3 dose. After the cessation of T3, serum T3 levels rapidly declined for the first $2 \mathrm{~d}$. Thereafter, mean serum T3 values plateaued and reached a nadir of $99 \pm 4 \mathrm{ng} / \mathrm{dl}$ on day 33 ( $5 \mathrm{~d}$ after $\mathrm{T} 3$ withdrawal). The concurrent mean serum T4 values of $3.2 \pm 0.5 \mu \mathrm{g} / \mathrm{dl}$ and serum TSH concentrations of $0.56 \pm 0.1 \mu \mathrm{U} / \mathrm{ml}$ were not significantly different from values observed during T3 suppression (days 3-28). During days 34 and 36 (6 and $8 \mathrm{~d}$ after T3 withdrawal), mean TSH rose to normal range with a parallel rise in serum T4. Subsequently, mean serum TSH rebounded to the upper limits of normal by day 40 and then fell to base line by day 44 . During this T3 withdrawal period there was a greater than twofold increase in serum T4, but only a $25 \%$ rise in serum T3 levels.

The three euthyroid subjects who had been administered 2 $\mathrm{U}$ of bovine TSH intramuscularly demonstrated a rise in mean serum T4 from $7.8 \pm 0.8$ to $11.9 \pm 1.6 \mu \mathrm{g} / \mathrm{dl}$ at $8 \mathrm{~h}$. Repeat TSH stimulation testing, performed $3 \mathrm{~d}$ after T3 withdrawal, showed

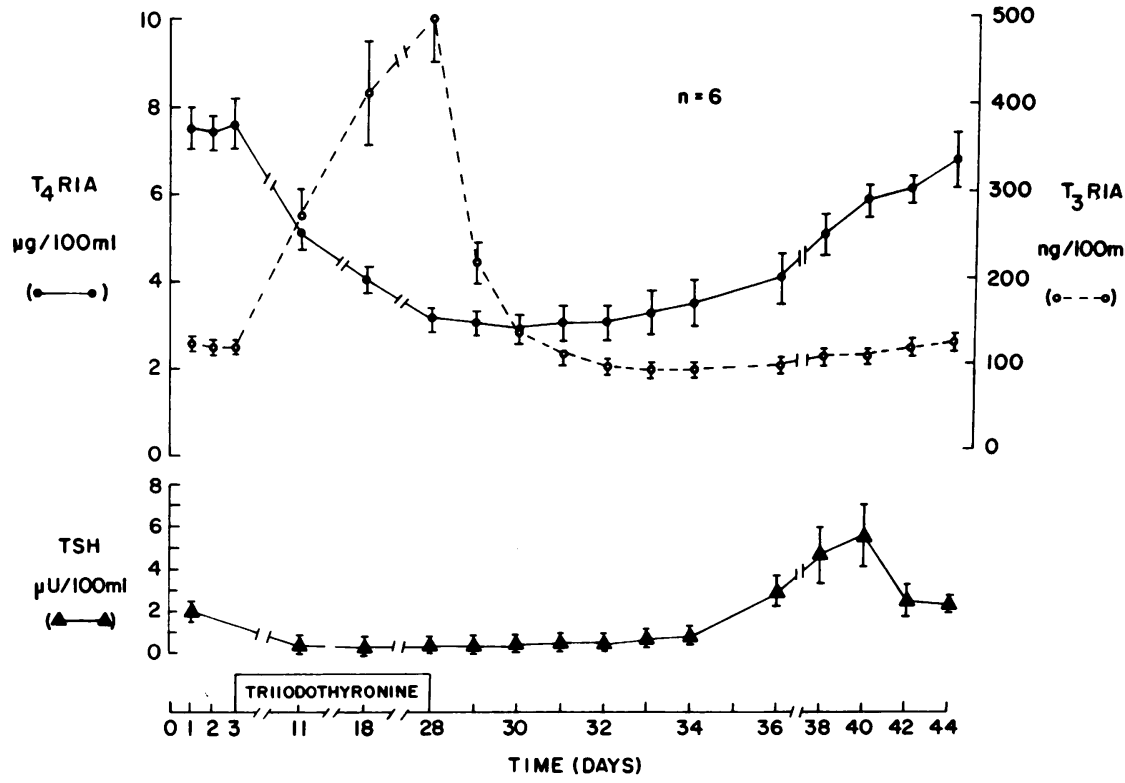

Figure 1. Serum T3, T4, and TSH concentrations (mean $\pm \mathrm{SE}$ ) in six euthyroid subjects before, during, and after withdrawal of $\mathrm{T} 3$. 


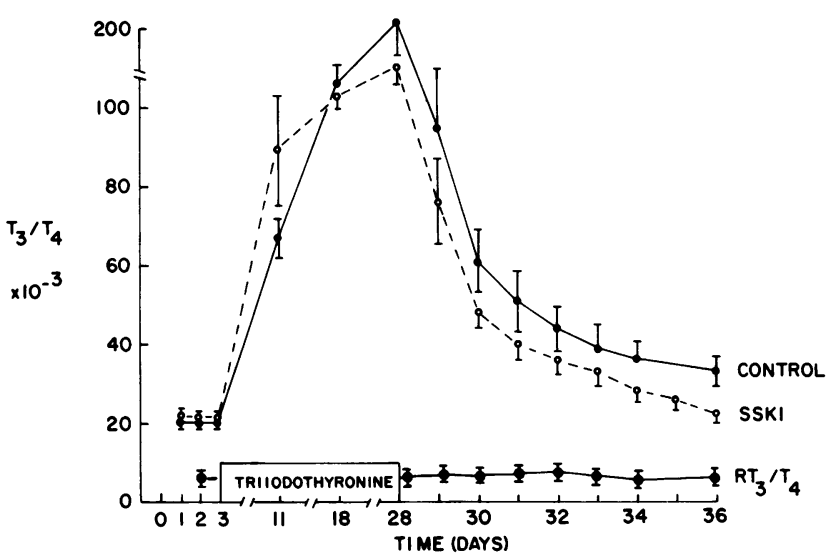

Figure 2. Comparison of $\mathrm{T} 3 / \mathrm{T} 4$ ratio values (mean $\pm \mathrm{SE}$ ) in the two groups of euthyroid subjects administered T3 with and without SSKI supplementation during the post-T3 withdrawal period. Changes in serum rT3/T4 ratio values for the control group were plotted in the lower portion of the slide.

a blunted response in mean serum T4 from $3.7 \pm 0.19$ to $4.7 \pm 0.3$ $\mu \mathrm{g} / \mathrm{dl}$. Similarly, the mean serum T3 response to TSH showed an increase from $119 \pm 12$ to $173 \pm 16 \mathrm{ng} / \mathrm{dl}$ during the control period, but only rose from $114 \pm 13.9$ to $128 \pm 4.2 \mathrm{ng} / \mathrm{dl}$ with repeat testing $3 \mathrm{~d}$ post-T 3 withdrawal. In terms of percentages, serum T4 response fell from 53 to $27 \%$ and serum T3 response fell from 45 to $12 \%$.

As can be seen in Fig. 2, identical serum T3/T4 ratio values were observed in the control and SSKI pretreated groups. Thus, prior exposure to pharmacological levels of iodides did not alter the pattern of serum T3 and T4 after withdrawal of exogenous $\mathrm{T} 3$. In contrast to the variability in serum $\mathrm{T} 3 / \mathrm{T} 4$ ratio values, serum rT3/T4 ratios were constant (range 5.1-7.8) and did not significantly vary throughout the study.

Comparison of mean serum $\mathrm{T} 3$ in athyreotic subjects who had been withdrawn from 6 wk of oral T3 with the euthyroid control group is shown in Fig. 3. The mean serum T4 values in the athyreotic group were $0.4 \pm 0.1 \mu \mathrm{g} / \mathrm{dl}$, indicating that residual T4 was present from previous T4 therapy. After T3 withdrawal, mean serum $\mathrm{T} 3$ levels plateaued at $27 \mathrm{ng} / \mathrm{dl}$, in contrast to $102 \mathrm{ng} / \mathrm{dl}$ for the euthyroid group. Final serum T3 values for euthyroid and athyreotic subjects on day 8 were $104 \pm 5$ and $21 \pm 1 \mathrm{ng} / \mathrm{dl}$, respectively. In one athyreotic subject placed on oral T3 for $12 \mathrm{wk}$, the serum T4 value was below the assay limit of $0.1 \mu \mathrm{g} / \mathrm{dl}$. Serum T3 levels fell below the assay limit of $10 \mathrm{ng} / \mathrm{dl}$ by day 4 after T3 withdrawal.

Fig. 4 shows a comparison of serum T3/T4 ratio values in a euthyroid control group with three euthyroid athyreotic subjects placed on T3 for 2 wk and then withdrawn. Nearly identical serum T3/T4 ratios were observed before study, during T3 administration, and for the first $3 \mathrm{~d}$ after T3 withdrawal. Subsequently, the athyreotic subjects maintained elevated serum T3/ T4 ratios, while those in the control group declined as the serum T4 levels rose. On day 8 after T3 withdrawal, the athyreotic subjects had mean T3/T4 ratios of $40 \pm 2$ as compared with control group values of $29 \pm 4$. On day 2 of $T 3$ withdrawal, serum TSH values gradually rose from $0.3 \pm 0.2$ to $6.3 \pm 2.6 \mu \mathrm{U} /$ $\mathrm{ml}$ on day 8 post-T 3 withdrawal in the athyreotic subjects. Since three of the athyreotic subjects participated in both the 2- and 6-wk treatment protocols, comparison of the serum TSH, T4, and $\mathrm{T} 3$ responses could be obtained. Mean serum T3 values were $51 \pm 3,50 \pm 3,46 \pm 3$, and $46 \pm 3 \mathrm{ng} / \mathrm{dl}$ on days $4-8$, while mean serum T4 values were $1.5 \pm 0.2,1.3 \pm 0.1,1.2 \pm 0.1$, and $1.2 \pm 0.1 \mu \mathrm{g} / \mathrm{dl}$, respectively, in the 2 -wk T3 protocol. In contrast, on the 6-wk T3 protocol, the serum T3 values were $28 \pm 2,25 \pm 3$,

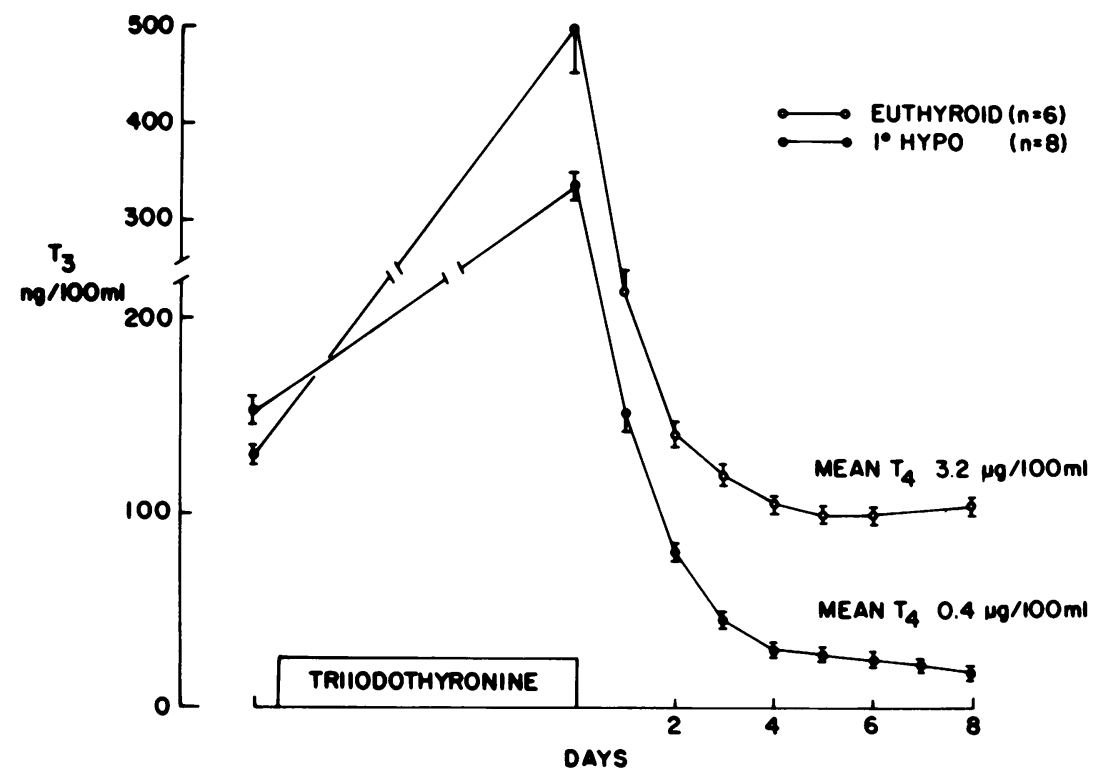

Figure 3. Serum T3 concentration (mean \pm SE) in euthyroid and athyreotic subjects during and after T3 administration. After 4 wk of T3 suppressive therapy, mean serum T4 value for euthyroid subjects was $3.2 \mu \mathrm{g} / \mathrm{dl}$. Mean serum T4 value after 6 wk of T3 administration was 0.4 $\mu \mathrm{g} / \mathrm{dl}$ in the athyreotic subjects. 


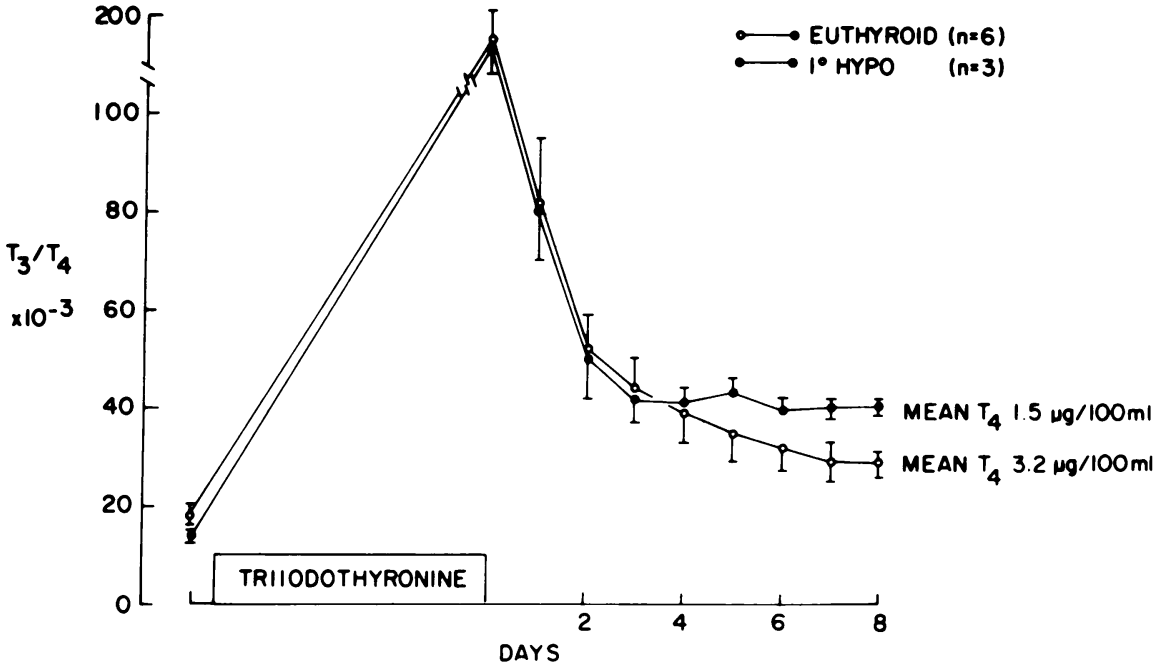

Figure 4. Comparison of the T3/T4 ratio value (mean $\pm \mathrm{SE}$ ) in euthyroid subjects placed on T3 daily for $4 \mathrm{wk}$ and then withdrawn and three athyreotic T4treated subjects maintained on $\mathrm{T} 3$ alone for two weeks before stopping.
$22 \pm 3$, and $21 \pm 3 \mathrm{ng} / \mathrm{dl}$, while the corresponding mean $\mathrm{T} 4$ values were $0.4 \pm 0.1,0.4 \pm 0.1,0.4 \pm 0.1$, and $0.4 \pm 0.1$, respectively. Serum TSH values were consistently $>10 \mu \mathrm{U} / \mathrm{ml}$ in this latter study. These observations are consistent with the view that the circulating $\mathrm{T} 3$ values measured in these subjects originated from peripheral T4 conversion rather than T3 secreted by TSH stimulation from a thyroid gland remnant.

\section{Discussion}

This study describes a phenomenon whereby serum $\mathrm{T} 3$ values are maintained when there is a deficient source of circulating T4 in eumetabolic subjects. Although the precise mechanism responsible for this phenomenon is unknown, it does not appear to result from alterations in the pituitary-thyroid axis for the following reasons: (a) Serum TSH values were subnormal in euthyroid subjects throughout the initial $6 \mathrm{~d}$ after T3 withdrawal; (b) intramuscular bovine TSH produced a blunted rise in serum T3 and T4 during this period, thus indicating reduced thyroid sensitivity to TSH; and (3) prior administration of pharmacologic iodides, which would be expected to inhibit thyroidal hormone release, had no influence on serum T3. In contrast, the finding of sustained elevations in serum T3/T4 ratios in three athyreotic subjects partially withdrawn from T4 therapy provided direct evidence of an extrathyroidal mechanism being responsible for this process.

Several possible peripheral tissue mechanisms could account for the increases in circulating T3/T4 with depressed T4 values. These include a slow back-diffusion of T3 into the blood of T3 stored in peripheral tissues during the period of oral T3 administration. However, this explanation appears unlikely since athyreotic subjects were unable to maintain serum T3 levels after T3 withdrawal, despite having similar elevations in serum $\mathrm{T} 3$ during $\mathrm{T} 3$ administration. Thus, it is essential that circulating
T4 be present to generate the $\mathrm{T} 3$ found in the circulation. Another possible factor is that a marked slowing of T3 clearance relative to T4 might account for the increased serum T3/T4 ratios observed at low serum T4 levels. Such a divergence in serum T3 and T4 clearance rates has been previously described in hypothyroidism (19). Whether these changes are a reflection of an altered state of metabolism or related to circulating T4 levels is unknown. In any case, it is doubtful that such differential changes in T3 and T4 clearances could account for the twofold increase in T3/T4 ratios. What appears to be the most likely explanation is that an autoregulatory mechanism exists for altering peripheral T4 to T3 conversion. The recent evidence for such autoregulatory 5 -deiodinase systems in rat pituitary, brain and brown adipose tissue which respond to T4 substrate levels provides independent evidence to support this possibility $(7$, 20-22).

A peripheral tissue mechanism for increasing T4 to T3 conversion in primary hypothyroidism and the reverse in states of chronic T4 excess has been previously described by Shimizu and co-workers (23) and Inada and co-workers (24). Further, Braverman and co-workers (25) have shown a decrease in T4 to $\mathrm{T} 3$ conversion occurring in euthyroid subjects after chronic oral T4 loads. Whether these apparent changes in T4 to T3 conversion are a result of an autoregulatory mechanism or are related to the metabolic consequences of hypo- or hyperthyroidism is unclear. It is unlikely that the changes observed in the present study resulted from hypothyroidism, since the subjects were essentially euthyroid at the time of study.

The mechanism responsible for producing alterations in serum T3 to T4 ratios after acute T3 withdrawal does not seem to influence rT3 metabolism, as rT3 to T4 ratios remained constant despite variable serum T4 levels. This is in contrast to the findings reported by Kaplan and co-workers (26) who observed an increase in rT3/T4 ratio values in association with 
depressed T4 concentrations associated with hypothyroidism. The exact cause for this disparity is unknown but may be a reflection that hypothyroidism per se may influence rT3 metabolism.

That a peripheral tissue mechanism may exist for maintaining circulating T3 levels in a state of T4 deficiency would seem compatible with the general pattern of evolution of human thyroid metabolism. For example, the evolutionary development of thyroxine binding globulin with its associated large extrathyroidal T4 pool is a reflection of the dominance of peripheral over central control in man. Further, TSH-induced changes in thyroid grandular secretion appear to play a relatively minor role in altering serum thyroid hormone indices found in association with fasting or systemic illnesses $(13-16,27)$ as contrasted to smaller mammals (28). However, the apparent importance of peripheral thyroid hormone metabolism should not be interpreted as indicating that there is only a minor role for the pituitary-thyroid axis in human physiology. Clearly, in states of iodine deficiency or thyroid gland failure, there is adaptive significance of the hypersecretion of TSH in promoting thyroidal T3 formation and secretion and in turn, maintaining serum T3 $(2,8,9)$. What seems most likely is that these two systems, peripheral tissue and pituitary-thyroid, act in a complementary manner to prevent decreases in serum $\mathrm{T} 3$ as circulating $\mathrm{T} 4$ values fall. The discovery of these multiple systems for sustaining circulating $\mathrm{T} 3$ levels underscores the physiologic importance placed on the precise control of circulating T3 concentrations in man.

\section{Acknowledgments}

The authors wish to express their appreciation to Ms. Lenore Curry for her technical assistance and to Mrs. Anne Santo and Mrs. Carol Goodman for their help in preparation and the illustrations and the manuscript.

This work was supported in part by National Institutes of Health grant AM-11727, General Research Center grant RR-43, and U. S. Public Health Service Training grant AM-07119.

\section{References}

1. Krugman, L. G., J. M. Hershman, I. J. Chopra, G. A. Levine, A. E. Pekary, D. L. Geffner, and G. M. Chua Teco. 1975. Patterns of recovery of the hypothalamic-pituitary-thyroid axis in patients taken off chronic thyroid therapy. J. Clin. Endocrinol. Metab. 41:70-80.

2. Larsen, P. R., J. E. Silva, and M. L. Kaplan. 1981. Relationship between circulating and intracellular thyroid hormones: physiological and clinical implications. Endocr. Rev. V. 2(1):87-102.

3. Reichlin, S., and R. D. Utiger. 1967. Regulation of pituitary thyroid axis in man. Relationship of TSH concentration to concentration of free and total thyroxine in plasma. J. Clin. Endocrinol. Metab. 27:251255.

4. Sawin, C. T., J. M. Hershman, and I. J. Chopra. 1977. The comparative effect of T4 and T3 on the TSH response to TRH in young adult men. J. Clin. Endocrinol. Metab. 44:273-278.
5. Yeo, P. P. B., M. Lewis, T. F. Davies, D. R. Weightman, J. Marshall, J. G. Ratcliffe, and D. C. Evered. 1979. The regulation of thyrotropin secretion by exogenous thyroxine and triiodothyronine. Clin. Chim. Acta. 99:203-210.

6. Larsen, P. R., T. E. Dick, B. P. Markovitz, M. M. Kaplan, and T. G. Gard. 1979. Inhibition of intrapituitary thyroxine to 3,5,3'-triiodothyronine conversion prevents the acute suppression of thyrotropin release by thyroxine in hypothyroid rats. J. Clin. Invest. 64:117-128.

7. Maeda, M., and S. H. Ingbar. 1982. Effect of alterations in thyroid status on the metabolism of thyroxine and triiodothyronine by rat pituitary land in vitro. J. Clin. Invest. 69:799-808.

8. Wu, S. Y. 1981. TSH-mediated induction of thyroidal iodothyronine monodeiodinase in dog. American Thyroid Association Meeting, T-21.

9. Erickson, V. J., R. R. Cavalieri, and L. L. Rosenberg. 1982. Thyroxine-5'-deiodinase of rat thyroid but not that of liver, is dependent on thyrotropin. Endocrinology. 2:434-440.

10. Braverman, L. E., S. H. Ingbar, and K. Sterling. 1970. Conversion of thyroxine (T4) to triiodothyronine in athyreotic subjects. J. Clin. Invest. 49:855-864.

11. Pittman, C. S., J. B. Chambers, and V. H. Read. 1971. The extrathyroidal conversion rate of thyroxine to triiodothyronine in normal man. J. Clin. Invest. 50:1187-1196.

12. Surks, M. I., A. R. Schadlow, J. M. Stock, and J. H. Oppenheimer. 1973. Determination of iodothyronine absorption and conversion of $\mathrm{L}-$ thyronine (T4) to L-triiodothyronine (T3) using turnover rate techniques. J. Clin. Invest. 52:805-811.

13. Carter, W. J., K. M. Shakir, S. Hodges, F. H. Fass, and J. O. Wynn. 1975. Effect of thyroid hormone on metabolic adaption to fasting. Metab. Clin. Exp. 24:1177-1183.

14. Gavin, L., J. Castle, F. McMahon, P. Martin, M. Hammond, and R. R. Cavalieri. 1977. Extrathyroidal conversion of thyroxine to 3,3'5'-triiodothyronine (reverse-T3) and to 3,5,3'-triiodothyronine (T3) in humans. J. Clin. Endocrinol. Metab. 44:733-742.

15. Schimmel, M., and R. D. Utiger. 1977. Thyroidal and peripheral production of thyroid hormones. Review of recent findings and their clinical implications. Ann. Intern. Med. 87:760-768.

16. Kaptein, E. M., W. J. Robinson, D. A. Grieb, and J. T. Nicoloff. 1982. Peripheral serum T4, T3 and reverse T3 kinetic in the low T4 state of acute nonthyroidal illnesses. A noncompartmental analysis. $J$. Clin. Invest. 69:526-535.

17. Challand, G. S., W. A. Ratcliffe, and J. G. Ratcliffe. 1975. Semiautomated radioimmunoassays for total serum thyroxine and triiodothyronine. Clin. Chim. Acta. 60:25-32.

18. Spencer, C. A., and J. T. Nicoloff. 1980. Improved radioimmunoassay for human TSH. Clin. Chim. Acta. 108:415-424.

19. Nicoloff, J. T., J. C. Low, J. H. Dussault, and D. A. Fisher. 1972. Simultaneous measurement of thyroxine and triiodothyronine peripheral turnover kinetics in man. J. Clin. Invest. 51:473-483.

20. Silva, J. E., J. L. Leonard, F. R. Crantz, and P. R. Larsen. 1982 Evidence for two tissue specifics pathways for in vivo thyroxine 5'deiodination in the rat. J. Clin. Invest. 69:1176-1184.

21. Visser, T. J., M. M. Kaplan, J. L. Leonard, and P. R. Larsen. 1983. Evidence for two pathways of iodothyronine 5 -deiodination in rat pituitary that differ in kinetics, proplythiouracil sensitivity, and response to hypothyroidism. J. Clin. Invest. 71:992-1002.

22. Leonard, J. L., A. Mellen, and P. Larsen. 1983. Thyroxine 5'- 
deiodinase activity in brown adipose tissue. Endocrinology. 112:11531155 .

23. Shimizu, T., C. S. Pittman, J. B. Chambers, M. W. Buck, and C. C. Thurston. 1975. The effect of thyroxine on the peripheral conversion rate of thyroxine to triiodothyronine in man. In Thyroid Research. J. Robbins and L. E. Braverman, editors. Excerpta Med. Int. Congr. Ser. 263-265.

24. Inada, M., K. Kasagi, S. Kurata, Y. Kazama, H. Takayama, K. Torizuka, M. Fukase, and T. Soma. 1975. Estimation of thyroxine and triiodothyronine distribution and of the conversion rate of thyroxine to triiodothyronine in man. J. Clin. Invest. 55:1337-1348.

25. Braverman, L. E., A. Vagenakis, P. Downs, A. E. Foster, K. Sterling, and S. H. Ingbar. 1973. Effect of replacement doses of sodium
L-thyroxine on peripheral metabolism of thyroxine and triiodothyronine in man. J. Clin. Invest. 52:1010-1017.

26. Kaplan, M. M., M. Schimmel, and R. D. Utiger. 1977. Changes in serum 3,3',5'-triiodothyronine (reverse T3) concentrations with altered thyroid hormone secretion and metabolism. J. Clin. Endocrinol. Metab. 45:447-456.

27. Harris, A. R. C., S. L. Fang, F. Azizi, L. Lipworth, A. G. Vagenakis, and L. E. Braverman. 1978. Effect of starvation on hypothalamic-pituitary-thyroid function in the rat. Metab. Clin. Exp. 27:1074-1083.

28. Croxson, M. S., T. D. Hall, O. A. Kletzky, J. E. Jaramillo, and J. T. Nicoloff. 1977. Decreased serum triiodothyronine induced by fasting. J. Clin. Endocrinol. Metab. 45:560-568. 